\title{
Fitness for the Muscles and the Mind
}

\author{
Incorporating Nia (Neuromuscular Integrative Action) into a \\ Drama-Pedagogical Teaching Unit on Thomas Brussig's Novel \\ Am kürzeren Ende der Sonnenallee
}

\section{Steffi Retzlaff}

\begin{abstract}
This paper describes the incorporation of a mind-body (fitness) technique called Nia into a drama-pedagogical teaching unit of Thomas Brussig's novel Am kürzeren Ende der Sonnenallee. The participants were third year university students of German at McMaster University in Hamilton, Canada. The focus is on the description of the preparation and execution of a seven-hour weekend workshop on Brussig's Sonnenallee. The 'prerequisites' for that workshop included research on life and resistance in the former German Democratic Republic (GDR) as well as a summary of the book and the production of character profiles for the main characters. The description of the workshop includes the portrayal of various activities such as the building of Standbilder (frozen frames), perception exercises und improvisations and, of course, the one-hour Nia session. According to the opinions of the students and my own experience and perception, drama-pedagogical elements and the inclusion of Nia have a great impact on the students' understanding of various texts and themes and make for a truly holistic experience.
\end{abstract}

\section{The Teaching Context}

The action-oriented project described here combines Neuromuscular Integrative Action (henceforth Nia) and drama to get to the heart of Thomas Brussig's novel Am kürzeren Ende der Sonnenallee. This book was one of the texts I had chosen for a third-year university course in German (ten students ranging in their proficiency from Intermediate German II to Advanced German I) in the fall/winter term 2007 at McMaster University Hamilton, Canada. The course reader also included short stories such as Ilse Aichinger's Das Fenster-Theater, Reiner Kunze's Schießbefehl and Wolfgang Borchert's Nachts schlafen die Ratten doch as well as two short theatre plays (Ruhe (un)sanft by Wolfgang Binder and Das Kartenhaus by Gabriele Seba), several poems, newspaper headlines, photographs and paintings by Renoir and Edward Hopper (among others). 
The idea was to introduce the students to a variety of texts and provide them with 'stimuli' that would spark their interest and trigger interaction. The whole course was based on an 'experiment', that is, it was explicitly advertised as 'learning German with all senses', as a course that would use the idea of Dramapädagogik as its underlying methodology. This meant, we would not use some drama activities 'here and there' but that the students would learn and apply new and 'old' methods each and every week (we met three hours each week and had one seven-hour workshop on a Saturday). Thus, the students were not only expected to 'be' creative and 'dramatic' but also to develop a thorough knowledge of various drama techniques. This knowledge would then be 'tested' in terms of the selection, application, justification and reflection of various methods in class as well as for the students' final presentation and through their Lerntagebücher (learning diaries). The evaluation criteria for this course reflected these requirements (see Appendix A).

Most of the students had been taking classes with me since September 2006 and had thus been already introduced to role play, improvisations and drama-pedagogical methods. They were used to group work and communicated mostly in German during class, which was taught in German. Furthermore, this course was enhanced by WebCT, the e-learning system used at McMaster University, and financially supported by the Centre for Leadership in Learning (CLL) at McMaster. CLL granted me $\$ 4000$ for the teaching project 'German with minds, hearts, hands and feet', which comprises two third-year courses. The first was taught from September 2007 to December 2007, and the second is running from January 2008 to April 2008. While the 2007 fall/winter term introduced a variety of texts and served as an introduction to drama-pedagogical didactics, the 2008 winter term introduces theatre movements and prepares the students for the public performance of a play in German. The final performance will take place at McMaster University and, with a view to strengthening the liaison between the university and other institutions and creating an interest in German, a possible second performance is planned at the Goethe-Institute Toronto.

In addition to the general objectives of improving and broadening the four language skills, students in these courses will develop and improve:

- body language, e.g. awareness of the body and of gestures and facial expressions;

- relaxation techniques and holistic fitness (combining well-being and physical activity with cognitive activity, e.g. through the incorporation of Nia and various relaxation techniques;

- acting, directing and improvisation skills;

- creativity;

- self-awareness and self-confidence as well as social competence through self and group experiences; 
- group cooperation and team spirit, e.g. through choosing which characters and which play they would like to develop, and through the process leading up to the final performance.

Furthermore, students will be introduced to major theatre methods, e.g. Theatre of the Oppressed, and Instant Improvisation. They will develop individual perspectives/insights as to what it means to work with these methods, which can lead to analysis and discussion of these methods and their possible application in foreign language teaching.

The remainder of this paper is divided into six parts. The first part summarizes Brussig's novel Am kürzeren Ende der Sonnenallee. I then introduce the Nia technique and its possible integration into the language classroom. This is followed by a description of the 'prerequisites' for the seven-hour workshop, which included the Nia session. The last three sections deal with the workshop, students' opinions and evaluations of the workshop, of working with drama methods in general, and present concluding remarks.

\section{Am kürzeren Ende der Sonnenallee - A Brief Summary}

Sonnenallee is set in the late 1970s in the German Democratic Republic (GDR) featuring a couple of teenagers in their early teens who go through pretty much the same things that every teenager has to go through: first love, music, awkward dance lessons, trouble with teachers and parents, thinking about future career choices, etc. The main characters are the following: Micha and his family, including his mother (Mrs. Kuppisch), his father (Mr. Kuppisch), his older sister and brother, and Uncle Heinz from West Berlin, who always 'smuggles' things he could have brought into the country legally. Then, there is Miriam (a very beautiful girl that everyone, and especially Micha, is attracted to), Wuschel, the music 'geek' and Rolling Stones expert, Mario, Micha's best friend and his existentialist girlfriend. Finally, there is also the $A B V$ (Abschnittsbevollmächtigter), the police officer who Micha and his friends make fun of and who, in turn, makes life for Micha and his friends difficult sometimes.

The Sonnenallee is an actual street which was divided by the Wall between East and West Berlin.

The book can be difficult to get through at times due to unfamiliar and very specific GDR vocabulary and some slang as well as some GDR-specific socio-political contexts. However, the 'Easy Reader' version of Brussig's novel published by Klett is shorter than the original and provides the students with visual explanations (i.e. pictures). In addition, there is an Interpretationshilfe by Michael Lammers available (see bibliography). The assignments that accompanied the book (see 'prerequisites' below) assisted the students' understanding and comprehension of the main plot and themes. In general, the students enjoyed the book because it provides an interesting and relatable look at the GDR. Brussig's Sonnenallee, while at times serious, takes a light(er), more 
humorous view of the past (Brussig was actually accused of being 'ostalgisch'1).

\section{$3 \mathrm{Nia}$ - The Art of Movement ${ }^{2}$}

Nia was created in 1983 by Debbie and Carlos Rosas who reside in Portland, Oregon, and continue to teach Nia classes and train others to become Nia instructors. Nia stands for Neuromuscular Integrative Action, and it is an artistic movement program set to complex, customized music that blends eastern and western instrumentation and sound. Students explore a wide repertoire of movement modalities, as Nia combines a diverse blend of concepts and philosophies from the worlds of the healing arts, martial arts, and dance, such as tae kwon do, tai chi, Alexander technique, aikido, yoga, jazz, and modern dance. Nia sessions explore various choreographies comprised of structured concerted routines and a portion devoted to free dance so that students can express their own movement styles in a more liberating way without any direct input from the instructor.

The movements used in Nia map directly onto the body's physiology (for example, the shoulder joint moves in five distinct ways such as flexion, extension, adduction, abduction and circumduction, and all those movements are utilized in a regular Nia class). By tapping into the body's natural movement resources, individuals taking a Nia class are guided to move in a more energy-efficient way. They begin to condition their cardiovascular system and tone supportive muscle groups so that they can move with ease, without feeling fatigued.

An important aspect of movement efficiency is also the conditioning of the nervous system. First of all, Nia regulates the autonomic nervous system to maintain a sense of equilibrium in the body. It also modulates the activity of the autonomic nervous system because many movements demand agility. Agility, in turn, improves reaction time. In this context, agility is defined as the ease with which one can slow down or speed up movement when cued to do so. As the energy of a Nia class builds up, the sympathetic nervous system responds, the blood flows to the skeletal muscles, and the heart rate intensifies. In this context, the body is cued to speed up. However, shortly afterwards, the movement repertoire changes, the music lessens in intensity, and the body is cued to slow down. In this situation, the parasympathetic nervous system needs to take over in order to relax and slow down breathing and heart rate.

Secondly, Nia taps into the function of the central nervous system. It stimulates the central nervous system when it challenges movement coordination. Many movements in Nia promote neural activity across both the right and the left hemispheres. For instance, one piece of choreography can involve the slow, circular motion of the right arm and, simultaneously, a fast kick with the left leg.

\footnotetext{
1 'Ostalgie' is a compound of the German words 'Ost' (East) and 'Nostalgie' (nostalgia). 'Ostalgie' denotes a feeling of longing for the life in the former GDR . On the other hand, however, it has been noted that 'Ostalgie' trivializes the oppressive reality of life in the GDR.

${ }^{2}$ I am indebted to Andreea Diaconescu for collaborating with me on this section of the paper. Her input and time is greatly appreciated.
} 
Movement coordination is improved when isolated movements such as those described above demand bilateral activity of the motor region in the brain.

Furthermore, Nia improves the functioning of the central nervous system because it stimulates sensory and motor processes. Sensorimotor training akin to the non-repetitive movements of Nia also improves connectivity across the regions in the brain responsible for both gross and fine motor skills (see Chouinard et al. 2006). This, in turn, has a beneficial effect on motor coordination, balance, and fine motor movement.

Auditory processes are emphasized as Nia is set to complex instrumental music, and the movements relate directly to the beat and the melody of the music used. For instance, the feet and the legs move to a pattern that maps directly on to the drum beat of the particular song, while the arms and the upper body express the melody of the rest of the instruments, such as the guitar, violin, or the singer's voice. Visual imagination is stimulated in Nia as the movements pertaining to the choreography relate a particular image or symbol. In her instruction, the Nia teacher will offer the class an image which relates symbolically to the movement. In this manner, the students can take the image and create a story in their own unique way. Finally, Nia classes also expand one's knowledge of the body's range of motion as the students are guided to pay closer attention to the sensations each movement offers. Nia uses anything ranging from powerful kicks, blocks, spirals, balancing poses, grounded stances, turns, to shapes in space. Students are guided to attend to the sensation of each movement as the repertoire changes dynamically.

Research in neuroscience has shown that cardiovascular movement that is non-repetitive and that challenges coordination such as Nia can have a profound effect on the health of the central nervous system. Studies have shown that this cardiovascular exercise increases the underlying systems that support cortical plasticity including neurogenesis (proliferation of neurons), metabolism and vascular function (Cotman et al. 2007; Schweitzer et al. 2006). Neurogenesis in the hippocampus (the memory center of the brain), in turn, has profound improvements in memory function.

Nia classes have helped individuals with different motor impairments as a result of disorders such as Parkinson's disease, multiple sclerosis, fibromyalgia, osteoporosis, and arthritis. The benefits of creative movement are not circumscribed to motor coordination but also include cognitive health. Hollmann et al. (2007) have shown that non-repetitive, stimulating cardiovascular activity is capable of counteracting age-related neuronal cell loss, thus improving not only cardiovascular fitness, but also higher level cognitive functions such as memory and imaginative thinking.

In order to ensure the delivery of the physical and mental benefits of Nia, certified instructors go through an extensive training before teaching their first class. There are four levels of Nia Training: White Belt, Blue Belt, Brown Belt, and Black Belt. Everyone begins with White Belt and upon completion of the Nia White Belt Intensive Training, people are eligible to teach Nia in fitness and health centres. This system provides a developmental process that is fashioned 
after the martial arts. Eligible teachers need to not only embody the movement forms and an in-depth understanding of the music that accompanies Nia, but they also go through their own personal growth.

Aside from the cardiovascular and neural benefits, Nia is an artistic practice that offers people the freedom to express themselves and emote through movement. The artistic aspect of Nia comes from the theory that movement is a form of universal language, and students taking Nia are encouraged, through the use of the music and choreographed routines, to express their personality and culture through their movements. In this manner, those taking Nia can personalize the choreography in their own way. Moreover, in a culturally diverse classroom a universal language can help foster cross-cultural understanding. The same applies to different cultures, languages, traditions, sets of beliefs and values as encountered and discussed in language and literature classes. The idea of movement as a universal language relates to the view of movement as archetypal. An archetype is a generic, idealized model or concept in which similar instances are derived, copied, or emulated. The concept of psychological archetypes was advanced by Swiss psychiatrist Carl Jung in 1919 (Jung 1989).

In Jung's psychological framework archetypes are innate, universal prototypes for ideas and may be used to interpret observations. In his view, archetypes reflect a kind of collective unconscious, a universal culture that people can relate to without necessarily having experienced it first hand.

The novelty of Nia does not only lie in its mental, physical and 'universal' benefits but also in the unlimited adaptability of the practice. Not only can people of various fitness levels participate, but a wide range of therapeutic, wellness, self-growth and educational models can effectively integrate Nia (for example, see Appendix B for an article about Nia in the July 26, 2003 Globe and Mail edition. In "Fit for Duty" on page F6, it is reported that Nia classes were the most popular ones on offer at a Canadian Armed Forces Base).

I personally take Nia classes and have been considering integrating Nia into language teaching for some time now. Together with Andreea Diaconescu, a Brown Belt Nia teacher from Toronto, I created a customized Nia routine for my students to accompany and deepen their understanding of the main themes and underlying values and beliefs in Thomas Brussig's novel Am kürzeren Ende der Sonnenallee. The three main themes I isolated were:

1. Enge und Restriktion (narrowness both physically but also in the sense of narrow-mindedness and restrictions in terms of the system and socialist ideology);

2. Erste Liebe (first love);

3. Widerstand (resistance).

Now, how could we integrate Nia into this thematic context? Before actually creating the choreography of the routine, Andreea and I explored the various aspects of movement, the physical, mental, and emotional ones. First of all, in 
terms of the physicality of the movements, we wanted to create choreography that related to the "sensation" of the themes. For instance, Enge und Restriktion required movements that were very restrictive and much more linear. In contrast, the theme Erste Liebe required movements that were circular, that stretched out the shoulder girdle and the rib cage, giving a sensation of freedom and openness. The symbolic themes that we worked with were also translated into movement so that the students could, in a sense, visualize them. The images were symbolic, because we wanted to inspire the students and encourage them to interpret the images the way they wanted to, without excessive guidance from our part. This portion of the exercise functioned to stimulate creativity and imagination. Finally, the emotional aspect of the movement was added to crystallize the themes. If students did not pick up the subtle symbols of the movements, the emotional energy added on top magnified the impact of those images and encouraged students to pay closer attention.

An important aspect of the class, however, was that it was 'silent' in the sense that the Nia teacher did not use verbal instructions. A single clap from the instructor cued the students that there was a movement change approaching. Other than this cue, no verbal direction was provided. We decided for this kind of class set to instrumental music, without any singing or voice-over, so that the themes could be the main focus of the choreography. Moreover, this allowed the students to interpret the movements in their own unique way. We stimulated imagination as we allowed each participant to create his or her own concept of each theme. The instructor offered the movement, but it was the students who interpreted them. In this manner, the students taking the class were actively participating in the creation of the story, contributing with their own interpretations of the themes.

\section{The 'Prerequisites'}

To get some initial insight into the book and the GDR context respectively, the students were asked to complete various assignments prior to the actual discussion, dramatization and Nia performance of key scenes and themes in the book. ${ }^{3}$ For example, while reading the novel the students were asked to take notes of a specific character and then to produce a character profile. In class, we agreed upon the following categories for the profile: age, interests, attitude(s), appearance, important events in the person's life, and relation to other characters (Beziehungskonstellation). One student was responsible for collecting the individual profiles and for organizing them into a table, which I then corrected where necessary, and posted on WebCT. Each student also wrote a summary of two pre-assigned chapters of the book which, again, was corrected and put on WebCT. Thus, before our Saturday seminar, people could 'refresh their memories' by scanning through the summaries and the character

\footnotetext{
3 The following link provided me with various ideas for 'prerequisites': http: / /ww . lehreronline.de/sonnenallee.php.
} 
profiles. This exercise also helped in the preparation of some scenes we acted out/improvised during the (workshop) day when the character profiles served as role cards (Rollenkarten).

Furthermore, students were split into two groups to make collages about life in the GDR and the Federal Republic of Germany (FRG) in the late 1970s and early 1980s. This served the purpose of making them aware that, although many of the daily problems teenagers were facing at the time were similar in East and West, the two German states were indeed very different. They differed not only in terms of ideology but also pop culture. The students were asked to research common images and symbols that reflected life in the two German states in the late 1970s and early 1980s and to explain and discuss their choices in class (see Appendix C). The research for the collages also helped them to get a basic understanding of plot events while reading.

One overarching theme in Sonnenallee is resistance. It is not so much resistance in the form of open opposition to the system but rather 'small' actions which are sometimes not even recognized as forms of opposition by the characters themselves. Some examples of actions of resistance include Mr. Kuppisch's constant announcement that he would write a complaint ("Ich mache eine Eingabe!') or Miriam's 'Rumgeknutsche' (to make out) with 'Wessis'. Some other forms of resistance in Sonnenallee are listening to forbidden music such as the Rolling Stones or adopting an existentialist lifestyle like Mario and his girlfriend do. They too listen to forbidden music such as the chansons of Edit Piaf and read forbidden literature such as works by Jean Paul Sartre. Furthermore, after Mario is suspended from school, they live a rather nonconformist life.

Since resistance was one of the themes we would translate into movement in the Nia part of the Saturday workshop, I wanted the students to do some research and to think about those and other forms of resistance. They were asked to look up the so-called Flüsterwitze of the GDR (i.e. 'unofficial' jokes that were told in the GDR). They also were asked to decide on one and explain it, that is, describe what flaw or deficiency of the GDR system is mockingly exposed in the joke. ${ }^{4}$ In the Saturday seminar, I asked them as part of an improvisation to discuss which character in Sonnenallee would tell what joke and why. Afterwards, they incorporated the joke into their scene.

\section{The Workshop and Nia Experience}

Our Saturday workshop started at 9:30 AM and was scheduled until 4:30 PM with an hour lunch break. Thanks to the grant from CLL, I was able to book space in The Pearl Company, an old warehouse/converted art gallery and beautiful theatre space located in downtown Hamilton. It provided an inspiring atmosphere and allowed for much interpretation and creativity with its huge

\footnotetext{
${ }^{4}$ See this link for various jokes at various periods of the GDR: (http://www.hdg. de/witze/ 7079.html).
} 
windows, old hardwood floors and great artwork. ${ }^{5}$

Most parts of the workshop were videotaped in a way that did not impinge on the students' performance. ${ }^{6}$ They had been videotaped various times before in class and the video material was used for observing and evaluating the learning and teaching process.

I started the workshop (which was conducted entirely in German apart from the occasional clarification in English) by familiarizing the students with the day's agenda. We then explored the room by walking around and taking in many of the subtle details of the space through a guided exercise. I asked the students to pay close attention to the space including the ceiling, floor, sides, and the furniture and other equipment in the room. I then called out 'stop' a couple of times and asked them each time to close their eyes and visualize the room. I solicited answers about the details of the room, such as how many doors, what is on top of the piano, what does the ceiling look like, etc. The students continued exploring the room, and while they were doing so, I asked them to find their favourite spot in the room and to go there. I then interviewed each student individually about their chosen spot and what was so special about it.

This exercise served two purposes: first, to leave the 'ordinary' world behind and to get the students into the mood for the day. It was also a preparation for the activities to follow which would use observation, visualization and description.

The students, still at their favourite place in the room, were now asked to visualize the setting of Sonnenallee. I invited them to describe the location by saying: "You are at the shorter end of the Sonnenallee now. What do you see? Who do you see? How are the colours? Are their any distinctive buildings?" The students then started to describe the Spielplatz (playground) where Micha and his friends would hang out; they mentioned the wall and also the grey buildings so typical of the former GDR. After some guided input, they also talked about the close proximity of the wall to the apartment buildings in the Sonnenallee and touched upon the small and overcrowded apartments as described by Micha in the book. This was taken up later in our discussion on the theme Enge und Restriktion. The students pictured Wuschel walking down the Sonnenallee with the Exile on Mainstreet record by the Stones clenched tightly to his chest. They also pictured the beautiful Miriam who turned everybody's head in the Sonnenallee.

The second part of the warm-up phase for the day comprised a physical activity to literally warm up the students for the Nia session. We played 'Simon says' and I guided the students through some stretches and easy movements. To play 'Simon says', we first built a circle. Then, I told the students only to obey me and perform the instructions when I first say the words 'Simon says.' I told

\footnotetext{
${ }^{5}$ In general, changing spaces and learning environments gives students new forms of stimulation and inspiration.

${ }^{6}$ Special thanks to Will Heikoop who videotaped the workshop and proofread this paper. Many thanks also to Jakub Kazecki who helped preparing the video clips.
} 
them they were out of the game if they follow an order that does not begin with 'Simon says'. Then I began by saying (in German) something like: "Simon says, put your left hand on your right knee," or "Simon says, jump on one leg" etc. I continued giving orders mixing it up saying something like: "Put your right hand on the left ankle," without prefacing "Simon says." The game continued until only one student was left.

By 10:15 AM we all gathered around a table and started a discussion on the novel clarifying some unfamiliar language use and plot development (the Easy Reader version of Sonnenallee provides reading comprehension questions in the back of the book as well as some grammar exercises). We paid particular attention to the three themes that would be translated into movement in the Nia session to follow: Enge und Restriktion, Erste Liebe, and Widerstand. In addition to an exchange of the research findings on forms of resistance in the GDR, the students worked in three groups to find examples for the three themes in the text and were then asked to use various drama-pedagogical techniques to represent their interpretations. The groups that worked on Enge und Restriktion and Widerstand used a sequence of Standbilder (frozen frames) to illustrate their ideas and understanding of these themes. Standbilder are "fotografische Momentaufnahmen", in which "Szenen und Handlungsverläufe fixiert und Zustände, Haltungen und Beziehungen ausgestellt und gedeutet werden" (Scheller 1989: 62). Thus, Scheller defines Standbilder as fotographic snap-shots, in which scenes and story-lines get fixed or frozen. States of being (emotional, physical etc.), attitudes and relations are exposed and interpreted in these snap-shots.

Standbilder are easy to build but it needs concentration and discipline since it is a silent activity. In other words, the HauptspielerIn (the builder) as well as the participating students are not supposed to talk. The HauptspielerIn selects students for the Standbild and puts them into the anticipated position and posture. He or she forms the posture and gestures of the students in the Standbild with her or his hands and shows the desired facial expression for the students to imitate. When the Standbild is finished the involved players are asked to 'freeze'. The HauptspielerIn then explains her interpretation and the rest of the class is invited to give feedback and discuss the Standbild. There are various other options of how to work with a Standbild, e.g. the 'Hilfs-Ich' where the HauptspielerIn walks into the Standbild and puts her or his hand on one of the player's shoulder to articulate this particular character's feelings and thoughts (see, e.g. Scheller 1998: 54 and 59-68, and 2004).

The concept Erste Liebe was exemplified by the demonstration of a Gedankenallee ('Thoughts-Avenue', see Kempe and Winkelmann 1998: 40). A conflict needs to be solved or a decision needs to be made. The person who must complete this task stands in the middle. Positioned on the right and left side of him or her are the other players (like an avenue). The one side represents a 'pro', the other a 'contra'. The person in the middle thus hears various opinions, thoughts and arguments he or she might not have thought about. This can, thus, help the person or the situation. There was a division in the class about Miriam's 
character. Some students said that although Miriam might be beautiful, she came across as shallow and dumb. In contrast, other students said that she just put on a charade but was actually very sensitive and insightful. Consequently, some in the class did not understand why Micha would fall for her. We, thus, used the Gedankenallee as an attempt to 'illuminate' Michas's choice. One side of the Allee voiced their opinions on the 'shallow' Miriam, while the other side took the opposite stance. In the end, the student who played Micha was to 'defend' (or not) his attraction to Miriam.

Since the students were already familiar with these techniques, the activities did not present any difficulties and brought much fun and interaction. We took a 15-minute break to get ready for the Nia session. The students changed into comfortable (sports) clothes, walked into the space, took off their shoes, and waited for the commencement of the class.

Nia is a barefoot technique. The sense of feeling grounded and stable both physically and emotionally begins with the feet feeling connected to the earth. The Nia instructor, Andreea, first gave a short introduction of what Nia is (see clip 1 ). She talked about how she had prepared three different routines to accommodate the three concepts we were working on all through the morning and in prior assignments. She then guided us through a Nia choreography and invited us to trust our instincts and to personalize our movements along the way. In Nia, the emphasis is less on following the steps and more on the individual's personal feelings and expressions. Normally, the moves are called out using vocabulary full of visual images (e.g. our bodies are waves or scarves, the arms are wings, and we would wave our tails from side to side). Andreea and I decided on a class without verbal cues so that English instructions would not interfere with the students 'German' mood and mindset. In a 'silent' class, the instructor indicates a change of movement or direction by clapping her hands twice one count before the new move or direction is executed. The idea of non-interference was also underlined by the music that Andreea had chosen, i.e. just music and sounds without lyrics. A very specific music arrangement was prepared by Andreea for each of the three themes to evoke specific physical and emotional reactions reflective of the three concepts. Nia, along with many other holistic approaches, is based on the assumption that our bodies are very much a part of all our learning; that is, learning is not an isolated brain function but can be effectively enhanced by the art and joy of movement. The three concepts Enge und Restriktion, Erste Liebe, and Widerstand were now translated into movement and music to create new or at least additional pathways in the brain to activate the storage of information regarding these concepts and new expressions or feelings (see clip 2) for an example of the routines on the concept Enge und Restriktion and Erste Liebe). One student said after the session that while dancing the Enge und Restriktion part she felt 'incarcerated' and 'blocked' wanting to be on the other side of the wall but all she could do was peeking at the wall "from the shorter end of the Sonnenallee", i.e. from the Eastern part.

The students also experienced the fact that Nia uses contrasting movements. These are beneficial in terms of coordination and connecting the right and 
left brain hemispheres allowing the information flow between the two. For example, upper body and lower body execute differently paced movements, or fluid, elongating stretches are juxtaposed with muscle-contracting martial poses and stances. Nia, thus, helps with body awareness and emotional awareness. It is a great way of keeping the students' creativity alive once they become less self-conscious and embrace the way their body moves and feels without judgement. Since the students did Nia for the very first time, conscious body awareness was a big stumbling stone. They noticed their lack of coordination and limited range of movements and generally felt a bit 'unfit'. They could not yet embrace the idea of 'letting go' and becoming less self-conscious. However, they really enjoyed the different take on German literature. They said that together with the other activities, Nia made for a unique physical activity and tool for interpreting German language and culture. The movement was also useful in terms of team building and developing cooperation and co-creativity (see below for more students' opinions).

After lunch and a discussion of their Nia experience, the students prepared for the final activity of the day: a semi-improvised scene. They scanned through the book with the help of the chapter summaries and character profiles they had prepared before the workshop (see 'prerequisites') and then took up the perspective of a certain character. I asked them to write down some sentences that epitomized that person's thoughts and feelings as well as direct quotes from that character in the novel. Each quote was written down on an individual small cue card so the students could easily access various sentences while acting out the final scene of our workshop. For that, we set up the Spielraum (playing area) reconstructing the living room of Micha's family, the Kuppischs, with Uncle Heinz' big armchair as central point of departure (we were fortunate to actually have a big comfy armchair as a prop). As part of that exercise, the students described the apartment, including the walls, furniture, borders, colours and other details. Raumbeschreibungen (descriptions of rooms) are a type of perception exercises which are an important prerequisite for the cultural and social empathy needed to act or improvise in specific contexts (see Raumbeschreibungen in Scheller 1998: 41-42). After defining the Spielraum, all students using props such as clothes, bottles, books, records etc., walked into the living room one after the other 'in character' and improvised a conversation based on the lines they had written on the cue cards. It was amazing to see how, after a while, the students really got into it adding their own interpretation and sentences to the text and the scene.

We ended a day full of activities in the living room of the Kuppisch family eating cookies, reflecting on the workshop, and wondering how it could already be 4.30 PM.

In the week following the workshop, we watched the movie Sonnenallee (by Leander Haußmann), compared book and movie version, and had a final discussion. As part of their writing assignments, students also chose one character from the book/movie and wrote a role biography (see Appendix D for an example). 


\section{Students' Feedback}

In general, students seemed to have enjoyed the drama-pedagogical approach to learning and teaching German and their Nia experience. Here is some feedback from the students' learning diaries:

Next came the Nia workshop. I particularly liked this, as it brought to movement the main themes about which we had spoken. I enjoyed the completely different take on a theme; one that used no words, only body language and motion.

At the weekend seminar we did many activities related to the book. I found that the Nia session was the most memorable. It was a completely new way for me to approach a text. I know that stories are acted out and danced out; I just have never done it myself. ... Overall, I really enjoyed our weekend seminar; it was so much fun to approach a text in so many different manners. I never thought that I would experience such an intimate approach to learning in university.

I also conducted an anonymous online survey at the end of the term which featured some questions on the Nia experience. ${ }^{7}$ Figure 1 represents the collected answers to the following four questions:

1. Was Nia a good additional element to understand the book and deepen the three concepts: Enge, Widerstand, Erste Liebe?

2. In general, should Nia be incorporated into second language learning?

3. Did you enjoy Nia as a physical/cardiovascular activity?

4. Would Nia provide a helpful preparation method in next year's theatre performance?

Here are some additional statements from the survey about Nia:

- I quite enjoyed doing Nia, it was interesting to build a connection between the movement and the themes of the literature.

- It was a little tricky to follow at first, but it was fun once I got the hang of it. Also, the interpretation was well done and I felt it helped me get into the text more.

- Ilearnthow to use movement as a literary technique into the understanding of a text.

- I thought Nia related well to the themes we discussed. It was a new and interesting perspective.

\footnotetext{
${ }^{7}$ Special thanks to my student Sabrina Silk who helped preparing the survey and compiling the answers.
} 


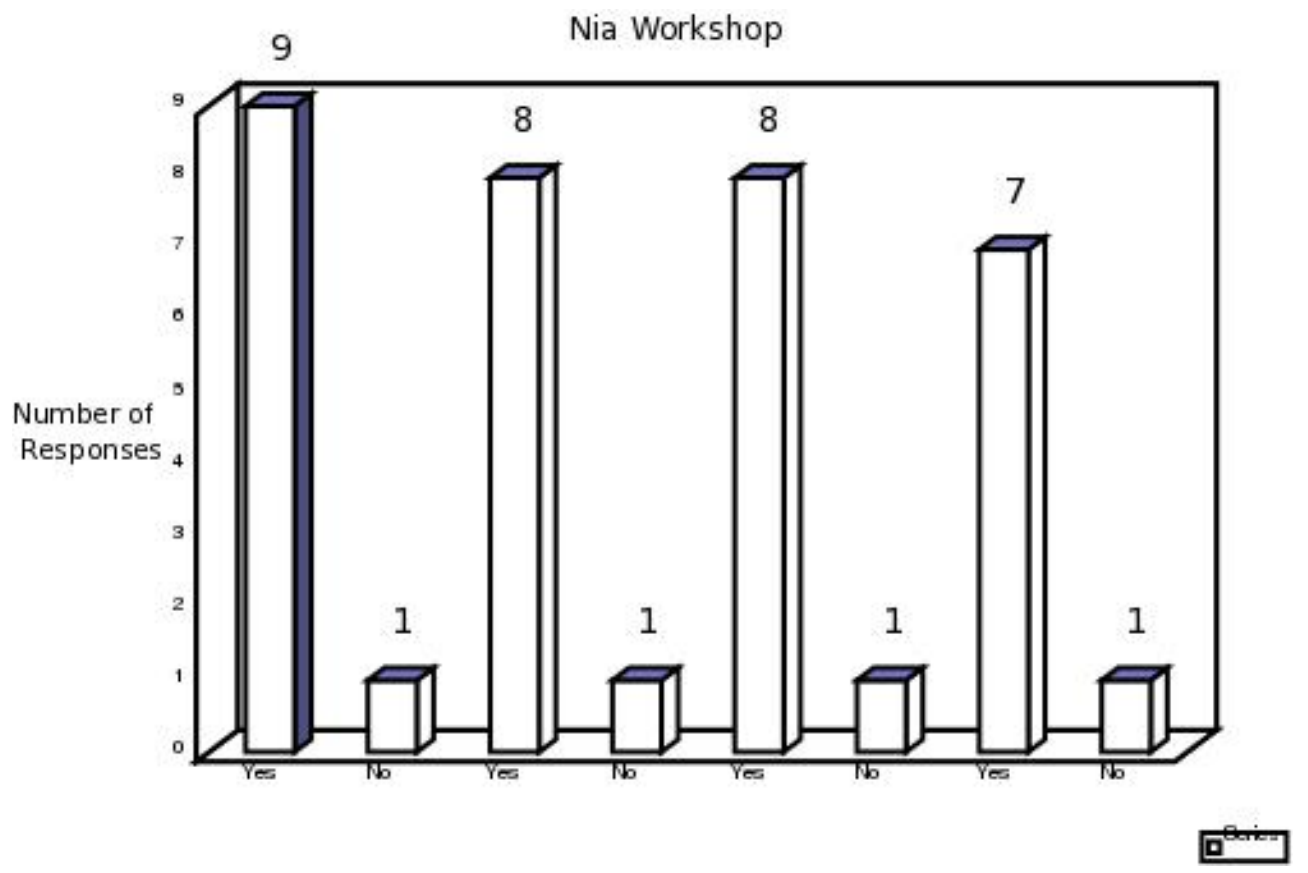

Figure 1: Student Answers

- It was a good physical movement related to the story.

- I liked Nia because it gave me a different level of the story.

Finally, some feedback from the online survey on the participants' opinions and evaluation of the course in general:

- Strengthened my language, learning and communication skills but overall taught me a valuable lesson that group work really helps learning and I am thankful for taking this class.

- This course helped me greatly increase my verbal skills in German. Also, the course helped me relax, as it was different from any of my other courses.

- Enjoyable, but very heavy workload. Felt pressure sometimes because we knew we would be put on the spot, e.g. der heiße Stuhl. Overall a good learning experience.

- At first, I found that this course would be quite intimidating and scary, but as it progressed and I became more familiar with the teaching techniques and the language, I have found it an enjoyable experience. I have been able to express myself more clearly and freely. Although, I feel my grammar is still lacking as far as language goes, I have overcome my biggest hurdle, which was to express myself and just speak. 
- At the outset of the course, I was skeptical and did not anticipate dramapedagogy to impact my listening comprehension and oral speaking skills to a great degree. To my surprise, this method not only strongly impacted my wholesome understanding of the German language, but it also buttressed my confidence in my own self and ability to express my thoughts and ideas. The method provided the class and me with an unparalleled opportunity, i.e. to delve into the realms of drama as a unique method of learning language comprehension. Dramapedagogy in all of its concomitant forms is a ground-breaking teaching strategy that should be incorporated into language teaching at the advanced level. This method is not only a language learning tool. It is more than that. It stretches far ahead and all the way into the never ending cycle of the learner's process of self-understanding and self-perception. Through a system of acting and drama, its various techniques are geared at teaching the student on how to use creativity in order to become relaxed, have fun and speak a language with greater confidence. This is the biggest barrier for all learners, namely letting go of the inhibition and fear of speaking. Dramapedagogy has therefore with no doubt achieved its learning goals in my case.

All of the students, who took this class with me, will continue and take next term's Advanced German I to II which will result in the public performance of a German play. The students said that Nia would be even more beneficiary for them then in terms of 'actor' training, i.e. expressing the body and releasing and letting go of the mind. This can help with stage fright and generally with getting to know one's body and self. The Nia instructor has happily agreed to come back to Hamilton to teach another session or two with the students.

\section{Conclusion}

The learning objectives and outcomes for a foreign language class such as German generally emphasize the development of skills in writing, reading and speaking as well as understanding spoken German (listening skills) and developing (inter-)cultural knowledge. However, the teaching of German often falls short of fulfilling these goals. Even after years of instruction, students do not gain the confidence of using the language in and outside the class room. Also, the students' willingness to engage with language, culture and literature depends to a great extent on the use of imaginative methodology on the part of the teacher. My training and education in foreign language teaching, linguistics, theatre and drama as well as my observation and experience in class have convinced me that the idea of holistic teaching and learning can lead the students from being passive recipients to becoming active creators of knowledge and ideas. The teaching project 'German with minds, hearts, hands and feet' is one way of involving the students more holistically, namely by means of drama, theatre and Nia. 
Nia nurtures the mind, body and spirit by improving strength, balance, posture, coordination, and stamina and provides a safe and joyful outlet for stress. In time, students will realize that it is all about them and their experience and expression and that nobody judges them. Nia is not about being a witness but rather about participation using one's own imagination and creativity, living in the moment and having fun. I believe Nia is a great method, not only to get the students fit but also to approach texts in a foreign language context. ${ }^{8}$

One of the basics that come across strongly in Nia is that Nia encourages people to love their bodies and to love what they are doing and thus to love and accept themselves. Nia can, therefore, help in 'healing' and letting go. "Through movement we find health" is the slogan associated with the Nia technique, and I truly believe that with time and more exposure to this practice it will resonate profoundly with my students in body and mind.

\section{Bibliography}

Brussig, Thomas (2004): Am kürzeren Ende der Sonnenallee (Easy Readers). Berlin: Klett

Chouinard, Philippe A./ Leonard, Gabriel / Paus, Tomáš (2006): Changes in effective connectivity of the primary motor cortex in stroke patients after rehabilitative therapy. In: Experimental Neurology 201 (2), 375-387

Cotman, Carl W. / Berchtold, Nicole C. / Christie, Lori-Ann (2007): Exercise builds brain health: key roles of growth factor cascades and inflammation. In: Trends in Neurosciences 30 (9), 464-472

Hollmann, Wildor / Struder, Heiko K. / Tagarakis, Christos V.M. / King, Gerald (2007): Physical activity and the elderly. In: European Journal of Cardiovascular Prevention \& Rehabilitation. 14 (6), 730-739

Jung, Carl G. (1989): Memories, Dreams, Reflections. New York: Vintage Books Random House Inc

Kempe, Andy / Winkelmann, Ulrike (1998): Das Klassenzimmer als Bühne. Donauwörth: Auer

Lammers, Michael / Brussig, Thomas (2000): Interpretationshilfe Deutsch: Am kürzeren Ende der Sonnenallee. Interpretationshilfe Deutsch. (Lernmaterialien). Freising: Stark

McMaren, Leah (2003): "Fit for Duty" in Globe and Mail. July 26, F6

Scheller, Ingo (2004): Szenische Interpretation. Selze-Velber: Kallmeyer

\footnotetext{
${ }^{8}$ I think its incorporation would be even more beneficiary when dealing with more 'difficult' and multi-layered texts such as Marie Luise Kaschnitz' short story Das dicke Kind which we also worked with in class. Here, we have a story in which traumatic unhandled childhood experiences influence the behaviour of adults. In the course of the story the librarian - one of the two protagonists - needs to recognize that she does not like the fat child because it reminds her of her own childhood as an unloved fat child. This story has an immense potential (but also carries immense dangers!) to connect the students to their own childhood experiences.
} 
Scheller, Ingo (1998): Szenisches Spiel. Handbuch für die pädagogische Praxis. Berlin: Cornelsen

Scheller, Ingo (1989): Wir machen unsere Inszenierungen selber I. Oldenburg: Zentrum für pädagogische Berufspraxis

Schweitzer, Natalie B. / Alessio, Helaine M. / Berry, Stephen D. / Roeske, Kirk / Hagerman, Ann E. (2006): Exercise-induced changes in cardiac gene expression and its relation to spatial maze performance. In: Neurochemistry International 48 (1), 9-16 


\section{A Appendix A}

\section{A.1 Evaluation Criteria for Course}

\section{A.2 (A) Bewertungskriterien für Anwesenheit und Partizipation}

Vorbereitung außerhalb des Unterrichts

- Alle Texte zum angegebenen Termin lesen und Aufgaben vorbereiten!

Mitarbeit im Unterricht (Gruppenarbeit und Einzelarbeit)

- Anwesend, wach und gut vorbereitet sein

- Diskutieren und Vorschläge machen, Ideenreichtum und Reflektieren

- Experimentierbereitschaft, Innovationsbereitschaft

- Offenheit und Engagement für Aufgaben, Übungen und Neues

- Risikobereitschaft

- Teilnahme am Samstagsseminar 10. November 2007

Beherrschen und Anwenden des szenischen ,Werkzeugkastens'

- Darstellung und Reproduktion szenischer Mittel und Verfahrensweisen

- Anwendung szenischer Mittel bei neuen Texten und Aufgabenstellungen

- Beschreibung und Analyse szenischer Strukturen und Mittel

- Auswahl szenischer Mittel, um ein Ziel zu erreichen

Soziale Kompetenz

- als Gruppenmitglied und Einzelperson:

- Kommunikations- und Interaktionsfähigkeit

- Toleranz, Teamgeist und Kooperation

- Offenheit und Kritikfähigkeit

- Engagement, Zuverlässigkeit, Pünktlichkeit 


\section{A.3 (B) Bewertungskriterien für die Abschlusspräsentation}

Planung und Organisation

- Zeitmanagement: Sie haben 50 Minuten

- Aussageschwerpunkte auswählen/szenisches Konzept entwickeln

- Struktur und Abfolge der Arbeitsschritte

- Auswahl der Methoden und Angemessenheit der Methoden

Analyse und Präsentation

- Textverständnis und Reflektion des Textes

- Reflektion der szenischen Umsetzung

- Sprachlich richtige Darstellung inklusive der Fachbegriffe

- Klare Arbeitsanweisungen an die Klasse

- Schriftlich: Begründen Sie Ihr szenisches Konzept. (ca. 2 Seiten)

Sprache und Ausdruck

- Angemessener Wortschatz und Ausdruck

- Gute Aussprache und Intonation

- Grammatische Richtigkeit

- Verständlichkeit und ,flüssiges' Sprechen

- Frei sprechen (Stichwortkarten sind erlaubt)

\section{A.4 (C) Richtlinien für das Lerntagebuch}

Das Lerntagebuch wird jede Woche geschrieben. Bitte schreiben Sie eine Seite oder mehr pro Woche. Mindestens 50\% des Lerntagebuches sollten auf Deutsch geschrieben werden. Bitte geben Sie das Lerntagebuch getippt und ausgedruckt bis zum 5. Dezember 2007 ab. Ich bewerte hauptsächlich den Inhalt des Lerntagebuches. Die Grammatik, der Stil und Ausdruck sollten jedoch verständlich sein. Der Inhalt des Lerntagebuches setzt sich aus zwei Teilen zusammen:

Teil I: Textarbeit

- Eine kurze Zusammenfassung des Textes, den wir gelesen und besprochen haben (inklusive des Textes für die Abschlusspräsentation/Abschlussprüfung). 
- Reflexion des Textes: Hat der Text mich angesprochen? Warum? Warum nicht? Gibt es einen Charakter im Text, der mich besonders interessiert? Warum? War der Text leicht, mittel oder schwierig? Welche neuen Wörter und Redewendungen habe ich gelernt (Nennen Sie einige Beispiele)?

Teil II: Reflektion der Unterrichtsmethode und des eigenen Lernens

- Eine kurze Rekonstruktion der Unterrichtsstunden: Was haben wir gemacht? Wie haben wir es gemacht? Und wie war die Stimmung in der Klasse?

- Reflektion der Methoden: Haben die ausgewählten Methoden (z.B. Standbilder oder Rollenbiographie) mir den Zugang zum Text erleichtert? Welche Methoden finde ich gut und warum, welche nicht?

- Reflektion des eigenen Lernens: Was für ein Lernertyp bin ich? Lerne ich besser, gleich gut oder schlechter mit allen Sinnen? 


\section{B Appendix B}

\section{B.1 Globe and Mail Article on Nia: "Fit for Duty"}

To access the Globe and Mail article on Nia please click here: „Fit for Duty“.

Source: McMaren, Leah:"Fit for Duty" in Globe and Mail July 26, 2003, page F6 


\section{Appendix C}

\section{C.1 Collages}

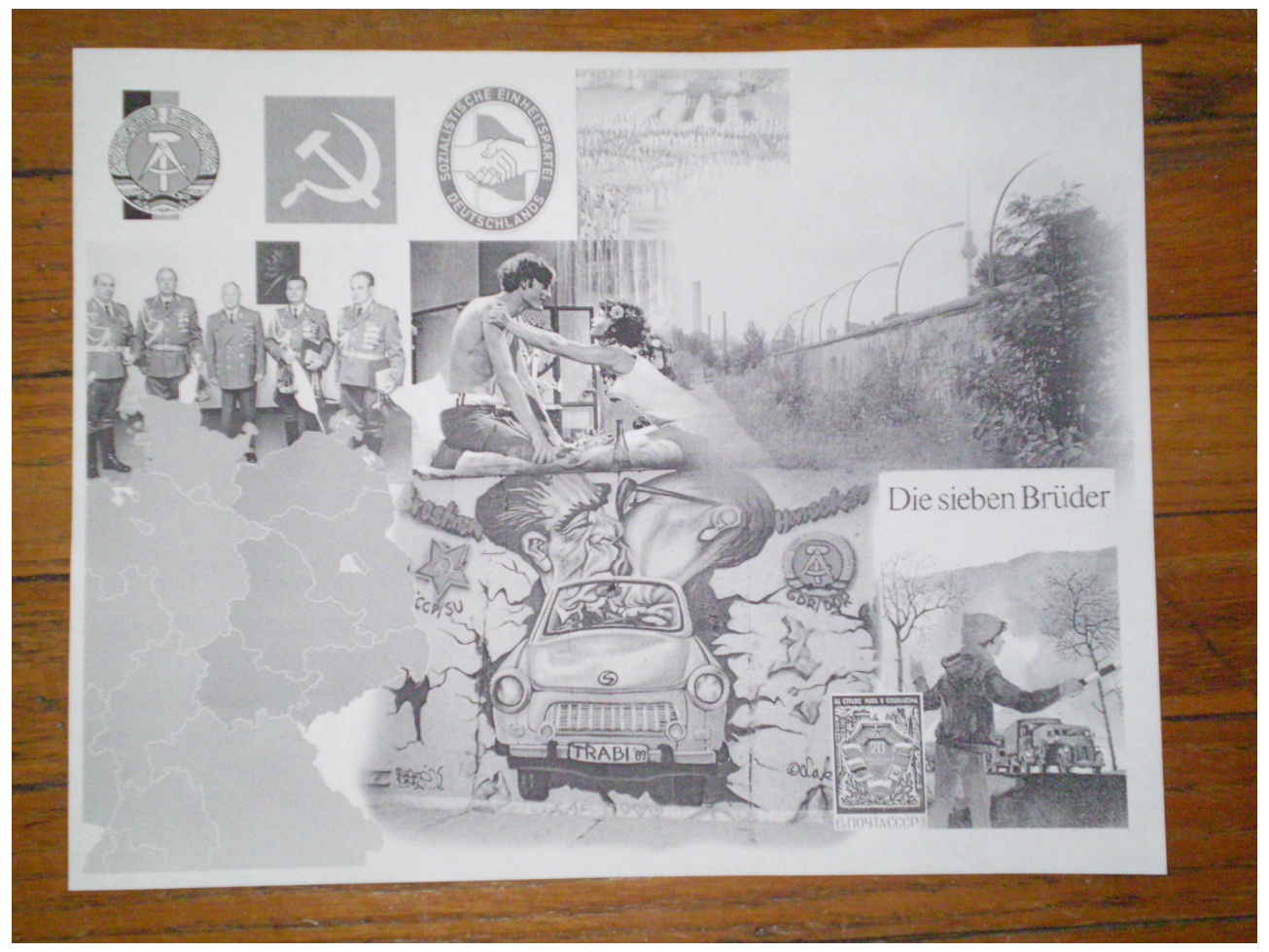

Figure 2: Life in the GDR 


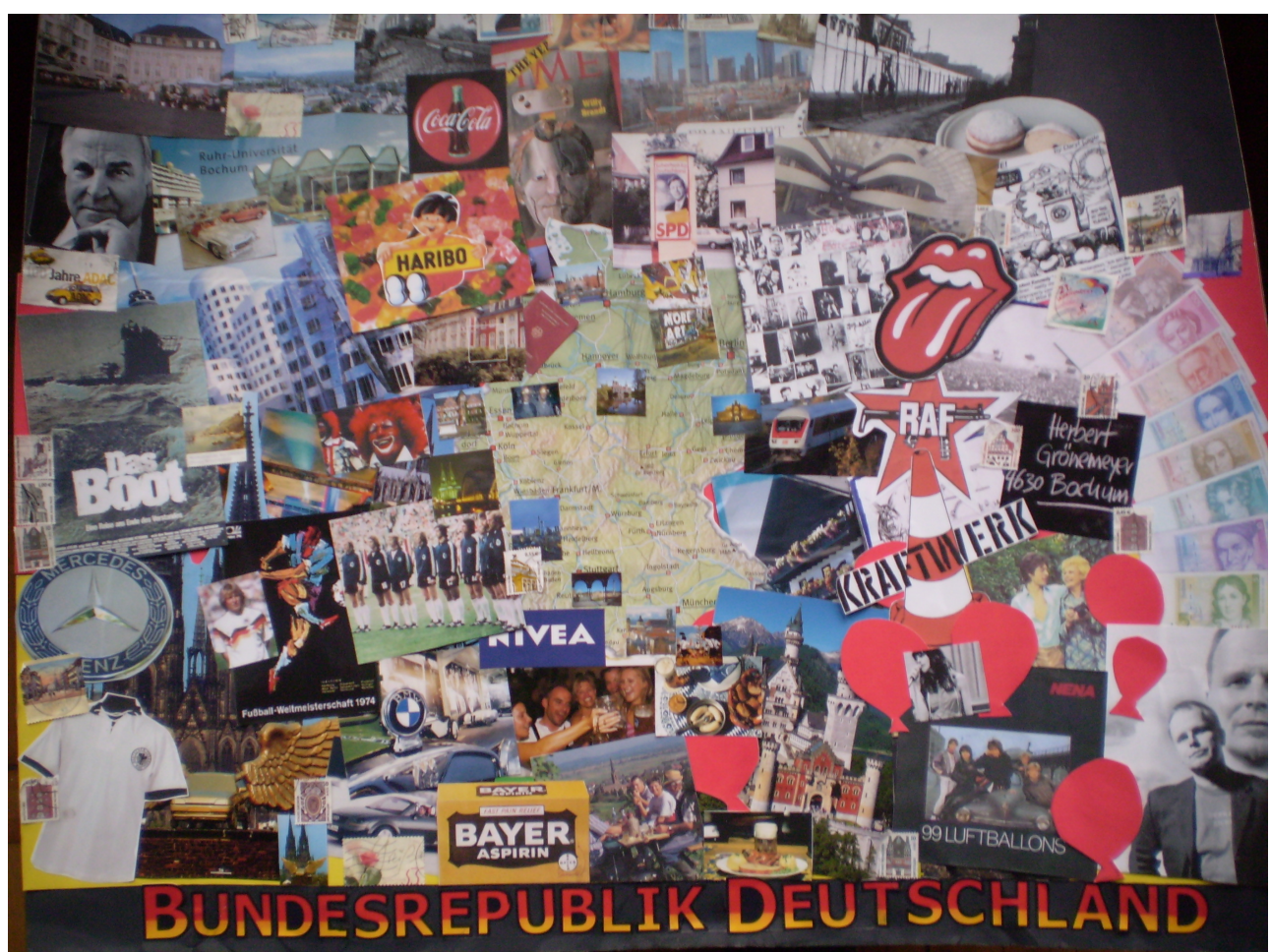

Figure 3: Life in the FRG 


\section{Appendix D}

\section{D.1 Rollenbiographie der Existentialistin}

\section{(Silvia Dimitrova)}

Ich heiße Danuta. Ich bin 31 Jahre alt und ich habe einen Mann und auch ein Baby. Ich habe eine liebevolle Familie und ich liebe mein Baby und meinen Mann. Ich passe auf meine Familie sehr auf.

Jedoch fühle ich mich unglücklich und deprimiert. Ich habe über mein Leben viel nachgedacht. Daher fühle ich mich so sentimental. Jetzt bin ich 31 Jahre. Allerdings habe ich in meinem Leben nichts erreicht. Ich habe ein kleines Baby und eine wundervolle Familie in der Mitte eines armen Landes, der DDR.

Als ich jünger war, wurde ich als "Die Existentialistin" tituliert. Ich war aktiv, motiviert und ich kämpfte für die Freiheit der Deutschen. Ich war emanzipiert, freimütig und ambitioniert. Ich strebte nach Freiheit für die Menschen und kämpfte auch dafür. Ich organisierte mindestens drei Proteste bei der Karl-Marx-Universität, zu der ich ging. Dort studierte ich Mathematik, Russisch und Physik. Allerdings war ich eine Rebellin, jedoch eine gute Rebellin für die Gerechtigkeit. Ich wollte sehen, dass die Leute in der DDR ihre Gerechtigkeit erhielten. Ich habe gedacht, dass sie nicht glücklich mit ihrem Leben sind, weil sie keine Gerechtigkeit hatten. Ich und mein Mann waren Rebellen denn wir konnten nicht zusehen, wie die Leute unterdrückt wurden. Wir wollten aus der DDR eine Demokratie machen. Und das ist was das Hauptziel meines Lebens war. Wir wollten Pink Floyd und The Beatles hören und die Welt sehen. Wir konnten nicht. Wir konnten nicht normale Leute sein, weil wir nicht sprechen konnten. Wir hatten keine Gerechtigkeit. Die Menschen sind keine Menschen ohne Gerechtigkeit. Das war, wofür ich und mein Mann, Mario kämpften. Ich erinnere mich, als Mario mit seiner Schuldirektorin und diesem Parteimensch konfrontiert wurde. Er war aber jung. Wir waren jung und noch nicht verheiratet. Mario war mit seinem Freund Micha. Sie wurden zu der Schuldirektorin kommandiert. Mario und Micha waren "die Menschen". Ja, sie waren tapfer und selbstsicher. Den beiden hat diese gemeine Frau die Aufrichtigkeit verweigert. Die Schuldirektorin zeigte auf ein Foto in der West Illusttrierten. Auf dem Foto warren Mario und Micha mit weit aufgerissenen Augen und bettelnd vorgestreckten Händen dargestellt. Unter dem ausdrucksstarken Foto stand: "Die Not im Osten - wie lange hält das Volk noch still?" Ja, das stimmt!!! Ich erinnere mich an diese Episode sehr klar und ich werde die niemals vergessen. Mein Mann und sein Freund haben im Namen der Menschen in der DDR so gehandelt. Mario wurde nach diesem Zwischenfall von der Schule geschickt. Na, ja! Das ist wie ein wirklicher Mann handeln muss. Deswegen fühle ich mich als eine stolze Frau.

Es ist klar, dass ich eine aktive und ambitionierte Jugendliche war. Aber nicht länger. Jetzt bin ich nur eine Mutter und eine Frau in einem armen Land - der DDR. Ich bete, dass sich die DDR und Westdeustchland sehr bald wiedervereinigen. Dafür mussten wir so lange kämpfen......Oh, das Baby wacht gerade auf und vielleicht hat es Hunger... 